University of Nebraska - Lincoln

DigitalCommons@University of Nebraska - Lincoln

Staff Publications: Biological Process

Development Facility

Biological Process Development Facility

1982

\title{
Bacterial Mosaic, a New Corynebacterial Disease of Wheat
}

Randall R. Carlson

University of Nebraska-Lincoln, rrcarlson11@gmail.com

Anne K. Vidaver

University of Nebraska-Lincoln, avidaver1@unl.edu

Follow this and additional works at: https://digitalcommons.unl.edu/bpdfpub

Part of the Biological Engineering Commons

Carlson, Randall R. and Vidaver, Anne K., "Bacterial Mosaic, a New Corynebacterial Disease of Wheat" (1982). Staff Publications: Biological Process Development Facility. 3.

https://digitalcommons.unl.edu/bpdfpub/3

This Article is brought to you for free and open access by the Biological Process Development Facility at DigitalCommons@University of Nebraska - Lincoln. It has been accepted for inclusion in Staff Publications: Biological Process Development Facility by an authorized administrator of DigitalCommons@University of Nebraska - Lincoln. 


\title{
Bacterial Mosaic, a New Corynebacterial Disease of Wheat
}

\author{
RANDALL R. CARLSON and ANNE K. VIDAVER, Department of Plant Pathology, University of Nebraska, \\ Lincoln 68583-0722
}

\begin{abstract}
Carlson, R. R., and Vidaver, A. K. 1982. Bacterial mosaic, a new corynebacterial disease of wheat. Plant Disease 66:76-79.

Bacterial mosaic is a foliar disease of wheat; characteristic symptoms are small yellow lesions, more or less uniformly distributed over the leaf. It was discovered in Nebraska in the spring of 1976. By 1979 , the pathogen was distributed over an $800-\mathrm{km}$ range and had been isolated from 16 cultivars of winter wheat. The pathogen is Corynebacterium michiganense subsp. tessellarius, a Gram-positive coryneform. Wheat was the only host that showed symptoms after inoculation. The pathogen reached high population levels $\left(>10^{6}\right.$ colony-forming units per gram of fresh weight) without apparent symptoms in tomato and in six of nine gramineous plants in greenhouse tests.
\end{abstract}

Bacterial mosaic is a foliar disease of wheat, the characteristic symptoms of which resemble the mosaic pattern of viral infections. The disease was widespread when it was discovered in Nebraska in 1976 and has been seen each year since. The causal organism is an orange-pigmented, Gram-positive coryneform identified as Corynebacterium michiganense subsp. tessellarius (Carlson \& Vidaver 1982). This report described

Paper 6587, Journal Series, Nebraska Agricultural Experiment Station.

Accepted for publication 4 September 1981.

The publication costs of this article were defrayed in part by page charge payment. This article must therefore be hereby marked "advertisement" in accordance with 18 U.S.C. $\$ 1734$ solely to indicate this fact.

0191-2917/82/01007604/\$03.00/0

- 1982 American Phytopathological Society

Table 1. Wheat cultivars from which bacterial mosaic pathogen was isolated and estimated 1977 Nebraska acreage

\begin{tabular}{lcc}
\hline Cultivar & \multicolumn{1}{c}{ CI } & Acreage (\%) \\
\hline Centurk & 15075 & 35.4 \\
Scout 66 & 13996 & 24.1 \\
$\quad$ (and Scout) & $(13546)$ & \\
Lancer & 13547 & 6.4 \\
Gage & 13532 & 5.7 \\
Buckskin & 17263 & 4.2 \\
Scoutland & 14075 & 3.4 \\
Homestead & 17264 & 1.7 \\
Sage & 17277 & 1.7 \\
HiPlains & 17262 & 1.6 \\
Lancota & 17389 & 1.5 \\
Sentinel & 17265 & 1.0 \\
Baca & 15891 & 0.8 \\
Larned & 17650 & \\
Vona & 17441 & $<0.3$ \\
Lindon & 17440 & \\
Agate & 17463 & \\
\hline
\end{tabular}

Estimated by the Nebraska Crop and Livestock Reporting Service. These cultivars represent more than $87 \%$ of total acreage. the symptomatology, population levels in natural and artificial infections, geographic distribution, and potential host range of the pathogen. The host specificity of the bacterial mosaic pathogen was compared with that of $C$. michiganense subsp. michiganense (Smith 1910) Jensen 1934 and $C$. michiganense subsp. nebraskense (Vidaver \& Mandel 1974) Carlson \& Vidaver 1982, two closely related pathogens of tomato and corn, respectively.

The other pathogens of wheat in the genus Corynebacterium, C. rathayi (Smith 1913) Dowson 1942, C. iranicum (ex Scharif 1961) Carlson \& Vidaver 1982, and C. tritici (ex Hutchinson 1917) Carlson \& Vidaver 1982, cause diseases characterized by gumming of the inflorescences. They were shown to be distinct from $C$. michiganense subsp. tessellarius by polyacrylamide gel analysis of cellular proteins (3). Some preliminary results have been presented elsewhere $(1,2)$.

\section{MATERIALS AND METHODS}

Isolation of the pathogen. Eighty isolates of the bacterial mosaic pathogen were obtained from winter wheat cultivars (Table 1) collected from Nebraska and Iowa during a 4-yr period (1976-1979). Isolations were made from leaf material using a direct puncture method (5, as modified in 16), or, more commonly, by grinding tissue in a sterile mortar containing $1 \mathrm{ml}$ of $0.0125 \mathrm{M}$ phosphate buffer, $\mathrm{pH}$ 7.1. Dilutions of the resulting slurry were made in phosphate buffer and plated on either CNS, a medium developed for the isolation of $C$. michiganense subsp. nebraskense (7), or NBY, a nutrient broth, yeast extract medium (14). They were then incubated at $25-28 \mathrm{C}$ until orange colonies were visible, usually about 4-7 days.

Media and cultures. Bacterial cultures were grown on either NBY or CNS. We used strains $C$. michiganense subsp. tessellarius $77113,77143,78181 ; C$. michiganense subsp. nebraskense CN761 ; and C. michiganense subsp. michiganense 14-4. Cultures of $C$. michiganense subsp. tessellarius have been submitted to the American Type Culture Collection, Rockville, MD, and to the Plant Diseases Division Culture Collection, Auckland, New Zealand, for deposit and reference.

Host range. Plants (Tables 2 and 3) were inoculated by the partial vacuum (6) or sewing needle technique (15). The

Table 2. Population levels of Corynebacterium michiganense subsp. tessellarius in plant hosts 7-10 days afer inoculation ${ }^{\mathrm{a}}$

\begin{tabular}{|c|c|c|c|c|}
\hline \multirow[b]{2}{*}{ Plant host } & \multirow[b]{2}{*}{ Cultivar } & \multicolumn{3}{|c|}{$\begin{array}{l}10^{6} \mathrm{CFU} / \mathrm{g} \text { of fresh weight } \\
\text { for strain }\end{array}$} \\
\hline & & 78181 & 77143 & 77113 \\
\hline \multirow[t]{5}{*}{ Wheat (Triticum aestivum) } & Centurk (CI 15075) & 9.2 & 8.3 & 18 \\
\hline & Tam W-101 (CI 15324) & 15 & 13 & 28 \\
\hline & Payne (CI 17717) ${ }^{\mathrm{b}}$ & 6.6 & 16 & 16 \\
\hline & Ramsey $(\mathrm{CI} 13246)^{\mathrm{c}}$ & 73 & 35 & 57 \\
\hline & Selkirk (CI 13100) ${ }^{d}$ & 6 & 7.2 & 50 \\
\hline Barley (Hordeum vulgare) & Larker & 0.57 & 7.3 & 1.6 \\
\hline Oats (Avena sativa) & Otoe & 5.3 & 20 & 3.1 \\
\hline Sorghum (Sorghum bicolor) & RS626 & 0.0071 & 0.0050 & 0.0041 \\
\hline Maize (Zea mays) & $\mathrm{GCB}^{\mathrm{e}}$ & 2.5 & 20 & 1.6 \\
\hline Teosinte (Zea mexicana) & & 0.330 & 0.280 & 0.034 \\
\hline Wild rye grass (Elymus sp.) & & 3.1 & 5.3 & 0.230 \\
\hline Smooth brome (Bromus inermis) & & 1.2 & 3.2 & 1.0 \\
\hline Shattercane (Sorghum bicolor) & & 0.027 & 0.022 & 0.024 \\
\hline Sudan grass (Sorghum sudanense) & Piper & 0.490 & 0.048 & 3.9 \\
\hline
\end{tabular}

${ }^{a}$ Plants were vacuum infiltrated. The assay procedure was precise to within a factor of two.

${ }^{\mathrm{b}}$ Hard red winter wheat.

${ }^{c}$ Durum wheat.

${ }^{\mathrm{d}}$ Hard red spring wheat.

${ }^{\mathrm{e}} \mathrm{Sw}$ weet corn. 
inoculum contained a suspension of bacteria $\left(1 \times 10^{6}\right.$ colony-forming units [cfu] per milliliter) and a wetting agent, Trydet TFA-11 $(0.1 \% \mathrm{v} / \mathrm{v}$; Emory Industries, Inc., Sante Fe Springs, CA). The plants were infiltrated under a vacuum of 250 Torr. Wheat was inoculated at the three-to four-leaf stage, corn was inoculated at the three-leaf stage, and one compound leaf of each tomato plant was inoculated when the plants were $6 \mathrm{wk}$ old. Other plants were inoculated when about $15-20 \mathrm{~cm}$ tall. All plant experiments were done in a greenhouse maintained at $19 \pm 3 \mathrm{C}$; no symptoms resulted when inoculated wheat was incubated at 15 or $25 \mathrm{C}$.

\section{RESULTS}

Symptomatology and host-parasite interactions. Yellow lesions with indefinite margins, typical of the disease, were found throughout the leaf to give the appearance of a mosaic (Fig.-1); hence, its common name. Individual lesions were similar to the hypersensitive rust reaction. The lesions could be found on any leaf of field-grown wheat, but competing foliar diseases could make bacterial mosaic symptoms difficult to detect; eg, the mosaic symptoms were initially found on leaves also showing lesions caused by Pseudomonas syringae. Lesions never became water-soaked in either artificially inoculated or naturally infected wheat, nor was bacterial streaming from lesions observed.
After inoculation in the greenhouse, symptoms were seen in 3-5 days, and they did not spread to uninoculated tissue. A severely infected leaf would turn brown and desiccate; such leaves could not be distinguished from naturally senescent ones. Disease development was consistent in wheat inoculated by vacuum infiltration but sporadic following inoculation using a sewing needle. Disease symptoms appeared in the field about the third week of May, just before heading; symptoms were not detectable in the fall or after the onset of leaf senescence. In the latter case, symptoms were obscured, but the pathogen could still be readily isolated from infected plants. Disease incidence and severity varied widely within fields.

Populations of $1 \times 10^{5}$ to $1 \times 10^{8}$ $\mathrm{CFU} / \mathrm{g}$ of fresh weight were found in field-grown wheat when assayed on CNS medium. The pathogen was primarily internal, because immersion in $0.5 \%$ sodium hypochlorite $(\mathrm{NaClO})$ for $3 \mathrm{~min}$ did not reduce cell numbers obtained from winter wheat leaves. Similar treatment of in vitro cells $\left(1 \times 10^{6}\right.$ $\mathrm{CFU} / \mathrm{ml}$ ) with $0.05 \% \mathrm{NaClO}$ reduced cell numbers more than $99.99 \%$. Preliminary results showed that the bacterial mosaic pathogen was seed associated; infestation was probably external, because treatment with $0.5 \% \mathrm{NaClO}$ killed the pathogen.

Geographic distribution. C. michiganense subsp. tessellarius was isolated from winter wheat grown in 17 counties of Nebraska and lowa (Fig. 2). These sites ranged from western Nebraska to western Iowa, a distance of more than $800 \mathrm{~km}$ (500 miles).

Host range. The pathogen was isolated from 16 cultivars of winter wheat grown in either commercial fields or demonstration plots; these cultivars were

Table 3. Comparative population levels of related Corynebacterium pathogens in compatible and incompatible hosts inoculated by vacuum infiltration ${ }^{*}$

\begin{tabular}{lcccc}
\hline \hline & \multicolumn{3}{c}{$\mathbf{1 0}^{\mathbf{6}} \mathbf{C F U} / \mathbf{g}$ of fresh weight } \\
\cline { 2 - 5 } Subspecies & Tomato $^{\mathrm{b}}$ & Corn $^{\mathrm{c}}$ & Wheat $^{\mathbf{d}}$ \\
\hline C. michiganense subsp. michiganense & 400 & 0.890 & 0.540 \\
C. michiganense subsp. nebraskense & 5.0 & 130 & 0.026 \\
C. michiganense subsp. tessellarius & 2.6 & 1.0 & 2.8 \\
\hline
\end{tabular}

"Symptoms were not seen in tomato vacuum infiltrated with $C$. michiganense subsp. michiganense nor in corn vacuum infiltrated with $C$. michiganense subsp. nebraskense; wound inoculation with these pathogens produced reactions in their compatible hosts.

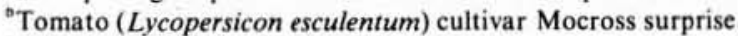

'Maize (Zea mays) cultivar Golden Cross Bantam.

${ }^{\mathrm{a}}$ Wheat (Triticum aestivum) cultivar Centurk (Cl 15075).
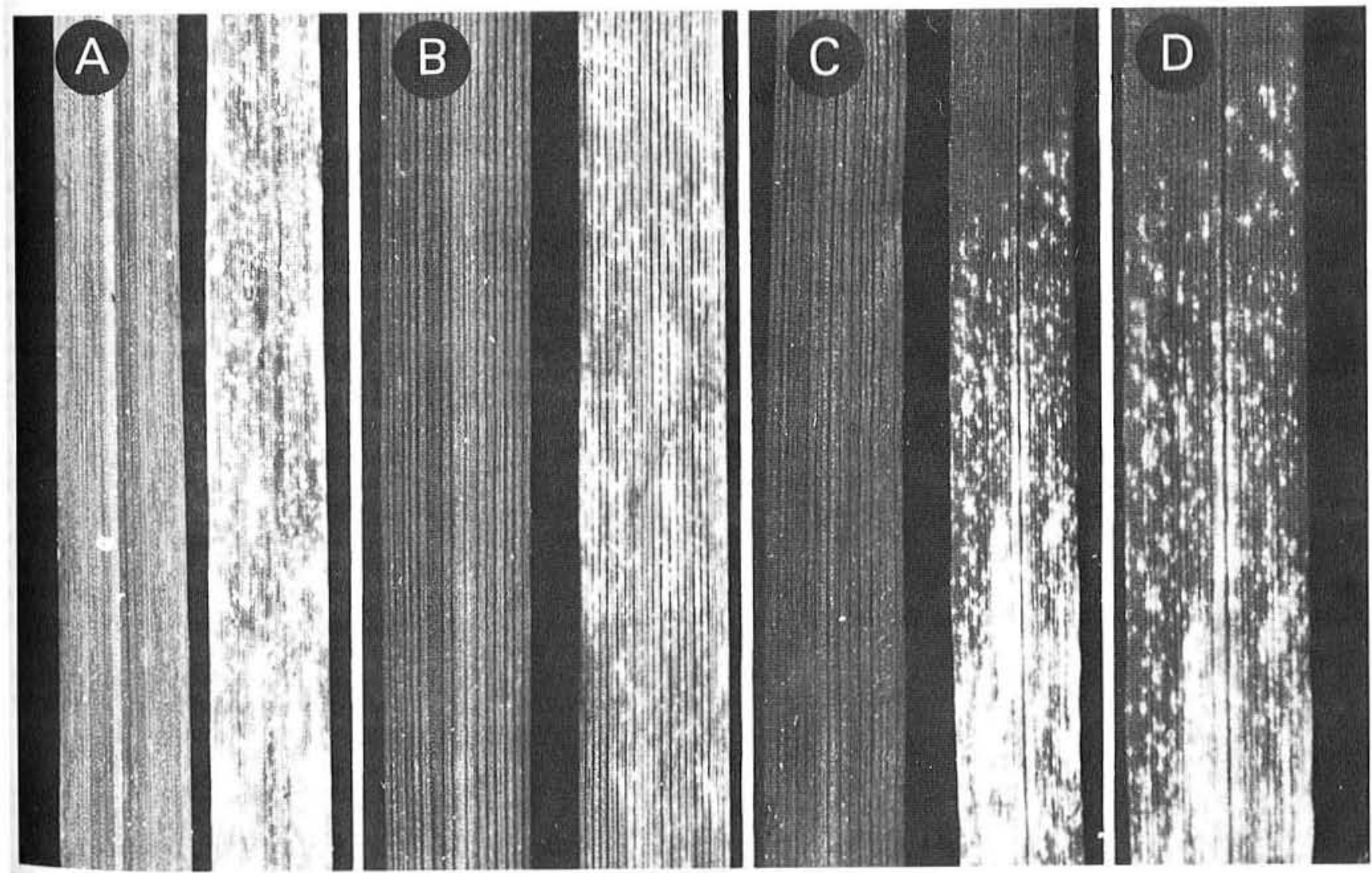

Fig. 1. Bacterial mosaic of wheat on leaves from plants inoculated by vacuum infiltration. The cultivars shown are (A) Payne, (B) Tam W-101, and (C,D) Centurk. Magnification is $\times 3$ for A-C and $\times 4.5$ for D. Control leaves are on the left in A-C. Note the indefinite margins of the lesions in D. 


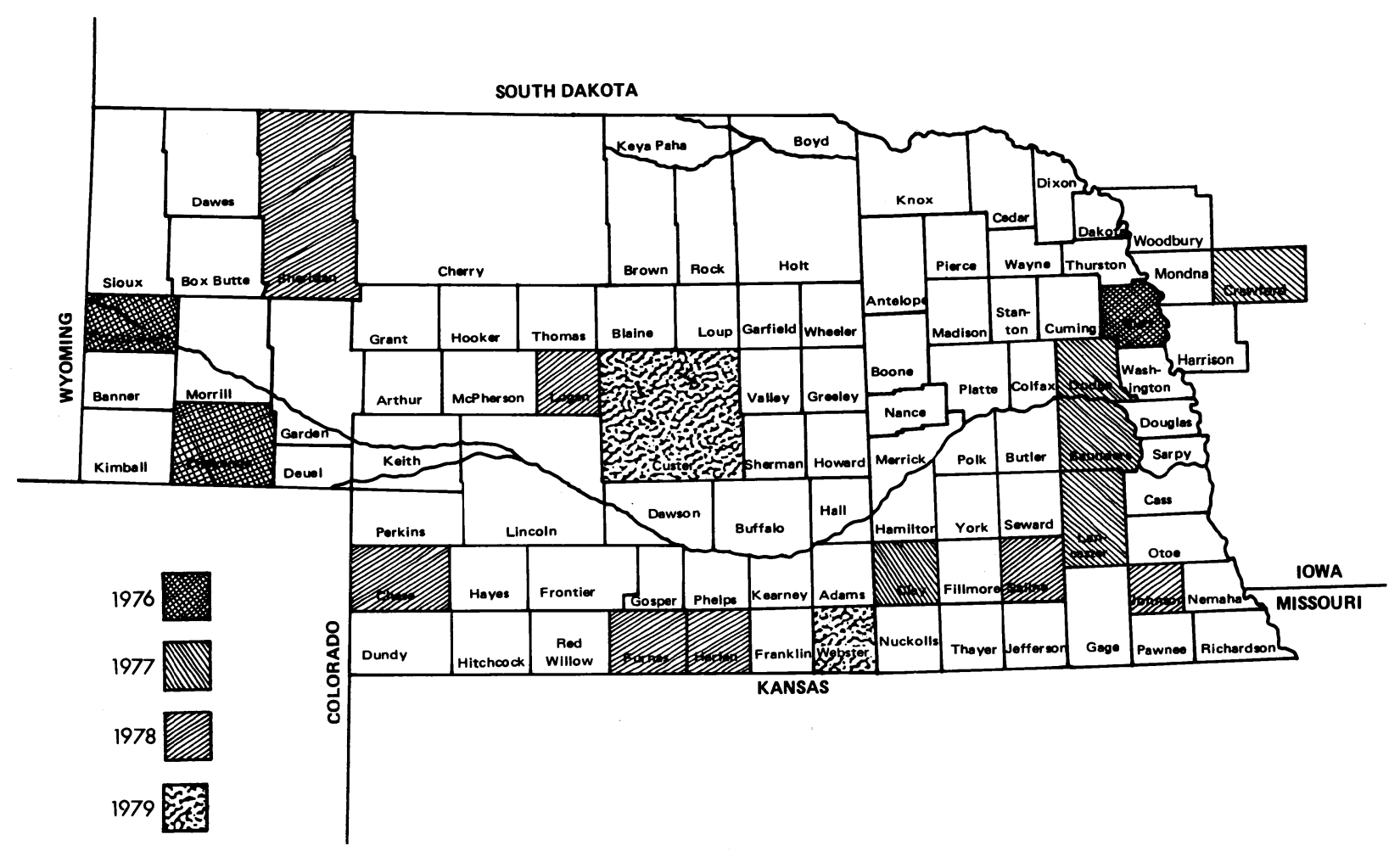

Fig. 2. Geographic distribution of bacterial mosaic of wheat in Nebraska and Iowa.

estimated to represent more than $87 \%$ of the 1977 Nebraska wheat acreage (Table 1). In greenhouse tests, the bacterial mosaic pathogen caused a typical disease reaction in the hard red winter wheat cultivars Centurk, Warrior, Scout, Gage, Payne, and Tam W-101; the hard red spring wheat cultivar Selkirk; and the durum wheat Ramsey. Pathogen populations in wheat ranged from 6 to 73 $\times 10^{6} \mathrm{CFU} / \mathrm{g}$ of fresh weight (Table 2).

No symptoms were seen in other grasses (Table 2) when artificially inoculated, even when $C$. michiganense subsp. tessellarius populations reached high levels. Immediately after inoculation by vacuum infiltration, populations were about $5 \times 10^{4} \mathrm{CFU} / \mathrm{g}$ of fresh weight; populations up to $2 \times 10^{7} \mathrm{CFU} / \mathrm{g}$ of fresh weight were found in symptomless plants sacrificed and assayed 7-10 days later. Populations greater than $1 \times 10^{6} \mathrm{CFU} / \mathrm{g}$ of fresh weight, when recovered from asymptomatic plants, were considered evidence of latent infections. Grasses that supported latent infections of the bacterial mosaic pathogen were barley, oats, sweet corn, sudan grass, wild rye, and smooth brome. Teosinte, sorghum, and shattercane did not support high populations of the pathogen.

In another study, tomato, sweet corn, and winter wheat were vacuum infiltrated with $C$. michiganense subsp. michiganense, C. michiganense subsp. nebraskense, or $C$. michiganense subsp. tessellarius in all host-pathogen combinations (Table 3). Populations of incompatible pathogehs were always less than the population of the compatible pathogen in each host; eg, the $C$. michiganense subsp. tessellarius population in wheat was much higher than the population of either $C$. michiganense subsp. michiganense or $C$. michiganense subsp. nebraskense in wheat. Wheat showed no symptoms when inoculated with either of the incompatible pathogens, and neither corn nor tomato developed symptoms when inoculated with the bacterial mosaic pathogen.

\section{DISCUSSION}

Bacterial mosaic is a disease of wheat caused by Corynebacterium michiganense subsp. tessellarius; it is the second plant disease caused by a Corynebacterium to be discovered in Nebraska in recent years. The other disease, Goss's bacterial wilt and blight of corn, is caused by a very closely related bacterium, $C$. michiganense subsp. nebraskense. One possible explanation for this coincidence is that our routine isolation medium, NBY, supports better Corynebacterium growth than some media used in other laboratories; detection of Corynebacterium pathogens is thus more probable. In the course of these studies, we also isolated an orange-pigmented bacterium from a native grass showing symptoms resembling I bacterial mosaic; it was indistinguishable from $C$. michiganense subsp. tessellarius and $C$. michiganense subsp. nebraskense by polyacrylamide gel analysis of cellular proteins, but it was not pathogenic to wheat or corn (Carlson \& Vidaver, unpublished data).

All wheat cultivars tested showed typical disease symptoms when inoculated with the bacterial mosaic pathogen. The ability of $C$. michiganense subsp. tessellarius to establish symptomless infections in plants other than wheat was an unexpected result. We do not know whether these latent infections are significant in natural disease progression, serving as a pathogen reservoir or as an overwintering stage. Latent infections by other phytopathogenic bacteria were reviewed by Hayward (8).

The absence of wilting in diseased plants and the inability of the disease to spread to uninoculated tissue in greenhouse tests suggest that the bacterial mosaic pathogen is not a vascular parasite. The lack of bacterial streaming from lesions may be a consequence of the pathogen populations in wheat leaves; other $C$. michiganense subspecies tested had higher populations in their natural hosts (see Table 3 ) and readily streamed from lesions. The host specificities of $C$. michiganense subsp. tessellarius, $C$. michiganense subsp. michiganense, and C. michiganense subsp. nebraskense were reflected in their respective population levels in wheat, tomato, and corn following vacuum infiltration, even though typical disease reactions in corn and tomato occurred only after wound inoculation.

The economic importance of bacterial mosaic of wheat is unknown, and further studies are needed to assess its impact.

\section{ACKNOWLEDGMENTS}

We thank M. G. Boosalis for bringing this problem to our attention and J. E. Watkins for assistance in sample collection.

\section{LITERATURE CITED}

1. Carlson, R. R., and Vidaver, A. K. 1979. Bacterial mosaic, a disease of wheat incited by a 
member of the genus Corynebacterium. (Abstr.) Phytopathology 69:1023.

2. Carlson, R. R., and Vidaver, A. K. 1981 Bacterial mosaic of wheat: Distribution and hosts. (Abstr.) Phytopathology 71:207.

3. Carlson, R. R., and Vidaver, A. K. Taxonomy of Corynebacterium plant pathogens, including a new pathogen of wheat, based on polyacrylamide gel electrophoresis of cellular proteins. Int. J. Syst. Bacterol. (In press).

4. Dowson, W. J. 1942. On the generic name of the Gram-positive bacterial plant pathogens. Trans. Brit. Mycol. Soc. 25:311-314.

5. Goth, R. W. 1965. Puncture method for isolating bacterial blights of bean. Phytopathology 55:930-931.

6. Gross, D. C., and DeVay, J. E. 1977. Population dynamics and pathogenesis of Pseudomonas vitro production of syringomycin. Phytopathology 67:475-483.

7. Gross, D. C., and Vidaver, A. K. 1979. A selective medium for isolation of Corynebacterium nebraskense from soil and plant parts. Phytopathology 69:82-87.

8. Hayward, A. C. 1974. Latent infections by bacteria. Annu. Rev. Phytopathol. 12:87-97.

9. Hutchinson, C. M. 1917. A bacterial disease of wheat in the Punjab. Mem. Dep. Agric. India Bacteriol. Ser. 1:169-175.

10. Jensen, H. L. 1934. Studies on saprophytic mycobacteria and corynebacteria. Proc. Linn. Soc. N.S.W. 59:19-61.

11. Scharif, G. 1961. Corynebacterium iranicum $\mathrm{sp}$. nov. on wheat (Triticum vulgare L.) in Iran, and a comparative study of it with $C$. tritici and $C$. rathayi. Entomol. Phytopathol. Appl. 19:1-24.

12. Smith, E. F. 1910. A new tomato disease of economic importance. Science 31:794-796.

13. Smith E. F. 1913. A new type of bacterial disease. Science 38:926.

14. Vidaver, A. K. 1967. Synthetic and complex media for the rapid detection of fluorescence of phytopathogenic pseudomonads: effect of the carbon source. Appl. Microbiol. 15:1523-1524.

15. Vidaver, A. K. 1977. Maintenance of viability and virulence of Corynebacterium nebraskense. Phytopathology 67:825-827.

16. Vidaver, A. K., and Mandel, M. 1974. Corynebacterium nebraskense, a new, orangepigmented phytopathogenic species. Int. J. Syst. Bacteriol. 24:482-485. 